\title{
Un viaje desde Costa Rica a Montevideo por los caminos de la femineidad Mujeres que cantan
}

\author{
Pilar de León \\ GETEA, Buenos Aires, Argentina - CIDDAE, Montevideo, Uruguay \\ piludeleon@gmail.com
}

Fecha de recepción: 19/05/2021. Fecha de aceptación: 30/06/2021.

En el artículo parto del análisis de Mujeres que cantan, espectáculo guiado dramatúrgicamente y dirigido por la costarricense Estíbaliz Solís Carvajal, llevado adelante por el Colectivo La Tijera en Montevideo, Uruguay y estrenado en época de pandemia. El espectáculo dialoga con la estudiosa de género chilena Alejandra Castillo y el filósofo francés Jacques Rancière.

La reflexión que surge es hasta dónde ese espectáculo solo para diez personas estuvo pensado por el espacio escénico o por las circunstancias actuales de pandemia. Este cuestionamiento responde a un cuestionamiento estético respecto a las artes contemporáneas.

Hay un diálogo entre hipótesis feministas y un campo de cuestionamiento realizado por materiales escénicos que me interesa poner en evidencia para sacar conclusiones teóricas respecto a qué es el teatro hoy. Hacia dónde se proyecta y cuáles son las voces que permiten ese diálogo.

Las imágenes desbaratan los cierres interpretativos, enlazan lo visible y desvinculan sus significaciones, desvían sentidos, alterando el marco de lo recto para volverse oblicuo, así como la palabra mediatizada y la escritura son el lugar de alteración y falla del dispositivo de la voz. En este caso la voz femenina.

\section{A Travel from Costa Rica to Montevideo along the Paths of Femininity. Mujeres que cantan}

I start the article from the analysis of Mujeres que Cantan, a performance guided and directed by Estíbaliz Solís Carvajal from Costa Rica and carried on by the collective group La Tijera in Montevideo, Uruguay with its premier during the pandemic. In this performance I observe the dialogue between a Chilean gender specialist, Alejandra Castillo and the French philosopher Jacques Ranciére. 
The observation that comes up is if the show was thought only for ten people for the scenic space or for the pandemic circumstances. This reflection is due to the esthetic circumstances regarding other contemporary arts.

There is a dialogue between hypothetical feminists and a questionable field made by scenic materials which I want to put in evidence in order to make theoretical conclusions about what the theatre is today, its projection and the voices this dialogue allow.

The images mess up the understanding closures, embrace the invisible and mislead its senses, putting the square frame into oblique also the use of mediatic language in the writing are the reason for this alteration and fails the voice. In this case, it's the female's voice.

KEYWORDS: CONTEMPORARY THEATRE, PANDEMIC THEATRE, FEMINISMS, OBLIQUE IMAGES.

Estíbaliz Solís Carvajal es costarricense. Es una verdadera artista escénica. Llegó a Montevideo hace algunos años y profundizó sus estudios, recibiéndose de Magíster en Ciencias Humanas, opción Teoría e Historia del Teatro y se especializó en Gestión Cultural, por la Universidad de la República (Uruguay). Como investigadora se ha dedicado al estudio de dramaturgias contemporáneas, poéticas y prácticas de creadores escénicos en el litoral uruguayo. Directora y dramaturga del Colectivo La Tijera, con sede en Uruguay desde el año 2012, ha estrenado ¿Cómo encontrar un portal mágico? (2013), Elárbol de naranjas (2015), Y los lugares comunes (2016), Lontano. La vida está en otra parte (2018), Cornucopia (2018) y Mujeres que cantan (2020), entre otros. Ha publicado dos libros de poesía y su creatividad poética queda en evidencia en el espectáculo que nos concierne.

Un espectáculo que nos ha permitido reflexionar acerca de la femineidad por múltiples caminos, una percepción de las mujeres desde cada una de nosotras, que nos interpela como espectadoras pero que también se hace cargo de presentar el arte como un espacio reflexivo y sensible a la vez

En Costa Rica, en San José específicamente, Solís Carvajal había montado un espectáculo: La pequeña y la verdadera (2007), en el cual se perfilaba su sensibilidad por el lugar de lo femenino. En una entrevista que le realizamos dice: "En la feminidad hay algo que se combate... Algo que se interviene o relee de manera oblicua [...] Hay algo que se desea... Algo creador, vivo, una elección propia y subjetiva desde la historia afectiva, desde las generaciones, lo que se decide afirmar, lo que se siente propio, lo que mueve al deseo, a la vida". Nos confiesa que antes de llevar adelante el proyecto Mujeres que cantan leyeron colectivamente a Alejandra Castillo, estudiosa de género chilena que dialoga con el concepto de "la imagen pensativa" de Jacques Rancière (2009). Intentaremos describir el espectáculo con el objetivo de comprender por qué asimilamos el análisis a la concepción de este teórico que afirma que el registro oblicuo es parte y no parte, al mismo tiempo, del orden de la representación que cualquier imagen deja ver y que en esta imagen se ponen en cercanía dos regímenes de expresión: por un lado, lo que se ve y por otro, su alteración. Esta alteración sería algo tan intangible como el tiempo, que pone en juego la desidentificación y lo anónimo.

Formulamos la hipótesis de comprender esta propuesta artística como una nueva manera de pensar, como un sistema de percepciones que provoca, interpela, se incorpora a la vida íntima de las mujeres para entender su voz. 
La autora nos cuenta que en 2018 había asistido a una casa donde había una peña artística, varios grupos musicales tocaban, había comida y bebida. De pronto, había empezado a sonar una de las bandas y se hizo un silencio profundo. Parecía que el tiempo se había detenido. Era la banda de Eliana Barrios, una de las $M Q C^{1}$. Estíbaliz Solís Carvajal observó la forma en que con su voz y su cuerpo había

"tomado la habitación, la pregnancia de su estar" y ese mismo día le dijo que "necesitaba hacer algo con eso y que la invitaría en cuanto tuviera diseñada una propuesta”.

Por otra parte, hacía mucho tiempo que sentía una deuda con su feminismo y propuso al Colectivo trabajar sobre la pregunta acerca de la existencia de algo así como "lo femenino" o la "feminidad". Para ello, empezarían leyendo algunos textos de teoría en relación con este apelativo, para ver de qué forma ingresaba en la historia familiar de cada una, con qué cargas, qué afirmaban y qué querían interrumpir.

Mujeres que cantan según sus propias palabras "es un montaje escénico multidisciplinar que se pregunta por la condición femenina a partir de la revisión biográfica, las prácticas de mujeres, el comportamiento de las flores y el canto de los pájaros"(2020). Como antecedente de este espectáculo hubo un Laboratorio de investigación escénica propiciado por el INAE (Instituto Nacional de Artes Escénicas) de Uruguay con el Colectivo La Tijera, en el marco de la Convocatoria Encuentros en la escena, en el cual de algún modo, se habían empezado a dar estímulos de instalación en la dramaturgia interdisciplinar . La importancia de "lo colectivo" en Solís Carvajal es tan esencial que ella afirma "yo no escribí la obra: guié la dramaturgia". "MQC es un espacio de encuentro, un proceso de investigación y una muestra de su propio espacio de acción: el canto" (Solís Carvajal, 2020).

El grupo está conformado por Karen Halty, Paola Larrama, Analía Valerio y la dramaturga- guía, pero siempre convoca según el proyecto; en este caso, lo hizo muy intuitivamente a quienes pensaba que podían cantar, empezando por Eliana Barrios, "pensando el canto como un hacer colectivo (la idea, como todo lo que hacemos, es crear, producir, realizar la escenografía, el vestuario, etc, nosotras mismas, todas haciendo juntas)", escribe en la entrevista. La metodología de trabajo pensada tuvo que adaptarse por la pandemia ${ }^{2}$. Costó hacerse a la idea pero cuando empezó a andar todo funcionó de forma muy natural, los objetivos continuaron siendo los mismos, sólo cambiaron los modos de trabajo y los medios.

Se estrenó en noviembre de 2020 en una fase de apertura, ${ }^{3}$ con todos los protocolos del caso ${ }^{4}$. El espacio es una casa, una casa con ocho habitaciones, ocho artistas y una realidad de 2020 que dio un giro a la concepción. Al mejor estilo de Virginia Wolf en Una habitación propia, la directora pensó que si tenía en mente la intervención artística, bien podía pensar la casa compuesta por cada una de las habitaciones reales de cada artista, instalando allí, su propio proceso creativo. "Con el zoom, desde donde enfrentábamos el encierro, cada una ayudaba a la otra. Creo que fue fundamental para el primer período de encierro lo que empezó a suceder en esas reuniones; era como salir para entrar en la habitación de otra, era encontrar relaciones entre nuestras

1. Escribiremos MQC cada vez que hagamos referencia a Mujeres que cantan.

2. En marzo de 2020 una pandemia de Covid -19 comienza a asolar el mundo y nos obliga a recluirnos en nuestras casas. Cada país tendrá sus protocolos de acuerdo a lo que los gobiernos consideren adecuado. Actualmente continuamos en fases diferentes según los continentes. La expansión aún no ha podido controlarse.

3. En marzo de 2021 se volvió a un período de recesión

4. Uso de tapabocas y alcohol en gel en las manos, distanciamiento social, pocos espectadores 
historias y presentarlas a través de estas habitaciones" (Solís Carvajal, 2020) Como si fuera una casa compuesta por ellas mismas. Thérèse Bertherat nos dice en El cuerpo tiene sus razones que cada uno habita su cuerpo como si fuera una casa. A veces uno no tiene la llave y desconoce su propio cuerpo (1987: 11). Marcando la analogía teórica lo que el Colectivo La Tijera propone es habitar nuestra propia casa, nuestra propia habitación y colectivizar esa vivencia a través de lo narrado. La casa es una composición colectiva, una casa que canta. Es llevar lo íntimo a lo público, y así tejer historias que corresponden al universo femenino. Hay un diálogo entre hipótesis feministas y un campo de cuestionamiento realizado por materiales escénicos. Como dice Estíbaliz Solís "Estamos todas dentro pero un día podemos abrir la ventana para que otras miren". La estructura del espectáculo con los subtítulos responde a la voz de la actriz nombrada. Es su voz.

\section{a. Apertura ${ }^{5}$}

Son diez espectadores, que al principio se dividen en dos recorridos: el Recorrido A y el Recorrido B. La casa está en ruinas. La primera habitación está ocupada por todas. Se invita a pasar a todos/as los/las espectadores/as, dándoles desde el principio la consigna del Recorrido que les corresponde. El centro está ocupado por una mesa con el té servido. Las actrices hablan con el público explicándole lo que sucederá: se les invitará a hacer un recorrido por toda la casa. Ofrecen té, galletitas. El público baja sus tapabocas para poder deleitar sabores. "Al involucrarnos sensorialmente, el teatro nos fuerza a reflexionar una vez más, pero desde una perspectiva diferente, sobre la forma, los alcances y los condicionamientos culturales y sociales del sentido o de los sentidos que otorgamos al discurso escénico y a los discursos artísticos en general" (Trastoy, 2018: 70)

El vestuario de las artistas está compuesto por vestidos y botas acordonadas, o de pronto, alguna sandalia perdida entre todas esas botas. La ventana que da a la peatonal Sarandí está completamente abierta. Debajo de la mesita del té hay colgantes con carteles diminutos que uno puede leer sólo si se aproxima. Murmullos, balbuceos, las actrices salen al balcón y vuelven a entrar. De a una, de a dos, de a tres. Un sutil sonido de viento pautado por la Directora es la orden para comenzar y para que suene una canción ${ }^{6}$ que habla de un pajarillo que vino a posarse cerca de un árbol, que se lamenta pero permanece en silencio, con un corazón dolido. Se mimetiza la historia de ese pájaro con el de las mujeres que habitan y cantan a capella en esa habitación. La canción surge como un lamento de las historias que nos narrarán, como un anticipo de lo que significa ser ave que en algún momento ha estado enjaulada y que ha logrado escapar, herida, lastimada. Estas mujeres terminan su canto diciendo:

Yo con mis voces escribo encima

de lo que se escribió

abro mi canto, abro la puerta

mira lo que quedó.

Según Judith Butler (2004) el poder del habla nos da el poder de la Performatividad, es decir, de decir y decirnos, de crear nuestra propia identidad. En estos versos de MQC hay una autorización a ser "voz", abriendo la ventana, pero también Solís Carvajal es consciente de que la voz femenina ha tenido que pasar por muchas capas para forjar su identidad en el discurso, por lo tanto en toda la puesta en escena la

5. Los subtítulos que van de a) a j) corresponden al programa de mano y escribiré en cursiva lo que está escrito en él

6. Pupila de águila de Violeta Parra en versión de Estíbaliz Solís Carvajal 
voz siempre sale mediatizada, o por una grabación, o por una escritura o porque se habla por teléfono a otro que no es el espectador o por el canto. La "voz femenina" ha estado acallada durante siglos. Sutil estrategia escénica que podemos comprobar en todo el recorrido.

\section{b. No espero nada de vos. / Karen Halty}

Me constituyo frente a vos en el acto de posar, de ser una imagen, sujeto. ¿Qué esperás de mí? Las escenas se suceden como en un documental. La imagen hace algo sobre quienes la observan. Ahí estás, estamos. No espero nada de vos.

Comienza el recorrido, grupo A y grupo B para las primeras instancias. Se invita a pasar a una habitación con instalaciones. Cada espectador/a hará el camino que desee pero debe pasar por todas las instalaciones.

"Patrice Pavis (2004) señala que, al menos en Europa, la preponderancia de la estética posmoderna no sólo se nota en la recurrente mezcla de géneros y de estilos que caracterizan a los espectáculos, sino en la museificación de las prácticas escénicas, a la que sucumbe el espectador: conserva en su memoria todo lo que ha visto, lo clasifica, lo ordena en forma de colección privada, aunque sin saber exactamente con qué fin lo hace" (Trastoy, 2018: 257-258). El orden se establece espontáneamente. Cada uno/a de los espectadores/as tendrá auriculares y pasará a intimar el vínculo con cada instalación en esa habitación. Se produce un diálogo íntimo. El piso tiene marcas. La voz de la actriz en los auriculares marca las pautas. Detalladamente aparecen marcas de estaciones: SILLÓN, PÁJAROS, ESCRITORIO, LIBROS. En cada estación surgen imágenes diversas, en SILLÓN, un tío que adoraba filmar es traído a escena a través de imágenes y las imágenes que aparecen en la pantalla son todas de mujeres. Mujeres en pose. Dice la actriz tomando palabras de Roland Barthes "yo me constituyo en el acto de posar" (1980: 25), como si se tratara de una pedagogía corporal necesaria para describir qué cuenta como sujeto impuesto por años por el orden masculino occidental. Alejandra Castillo, la estudiosa de género chilena, tiene al respecto una visión binaria masculino/ femenino/ que quizás no condice con la discursividad de Butler y con la que sustenta mi postura personal respecto al género pero de todos modos a la hora de comprender que las MQC trabajaron con esta teórica, puedo entender que escuche en mis auriculares: "Me fabrico instantáneamente otro cuerpo. Me matamorfoseo por adelantado en imagen" Y en esta exposición de cuerpos, la actriz, a través de los auriculares, nos habla del tiempo, de los conflictos entre cuerpos funcionales o eficientes, normales o patológicos, "organizados en espacios de dominio, inclusión, segregación, formas de una identidad". La preocupación de esta mujer que canta en este comportamiento museístico, de instalación, nos expresa de la posibilidad contemporánea de sintetizar el arte en una obra que trasciende la puesta en escena para acomodarse a una nueva forma de hacer teatro: intimista, confesional, autobiográfica, casi poética o filosófica. De estas imágenes de mujeres en malla de la década del cincuenta, pasamos a la estación ESCRITORIO que de algún modo nos muestra el caos y el orden. Y la escritura pasa a ser la orden que la actriz nos da. Debemos escribir en un cuaderno. Como si en el "escribirnos" se produjera un acto colectivo: "eso cantan muchas mujeres juntas" y dicta acciones de las más diversas, pasivas, activas, sencillas, complejas, placenteras, pero todas posibles y que unen las acciones como si todo pudiese ser "cantado". La metáfora de los pájaros dice mucho: la última orden que nos da la actriz es que pintemos una jaula con una puerta abierta y que mezclemos las semillas como si fueran nuestro propio alpiste. Ese pájaro herido al que alude la primera canción y que de algún modo en el último lugar del recorrido nos llevará a volar. Antes de salir de esta primera habitación, la de Karen Halty, se 
nos vendan los ojos. Y se escuchan notas de un instrumento solitario, como si nos encontráramos en la profundidad íntima y sola de nosotros/as mismos/as.

En la transición con la segunda habitación nos encontramos con una chimenea llena de objetos de costura acumulados. Objetos obsoletos en algunos casos. Seguimos nuestro recorrido.

\section{c. A room of her own. / Paola Larrama}

La habitación que nuestras abuelas no pudieron tener. Escribir una historia de amor que reescriba todas las historias de amor, incluso con sus palabras.

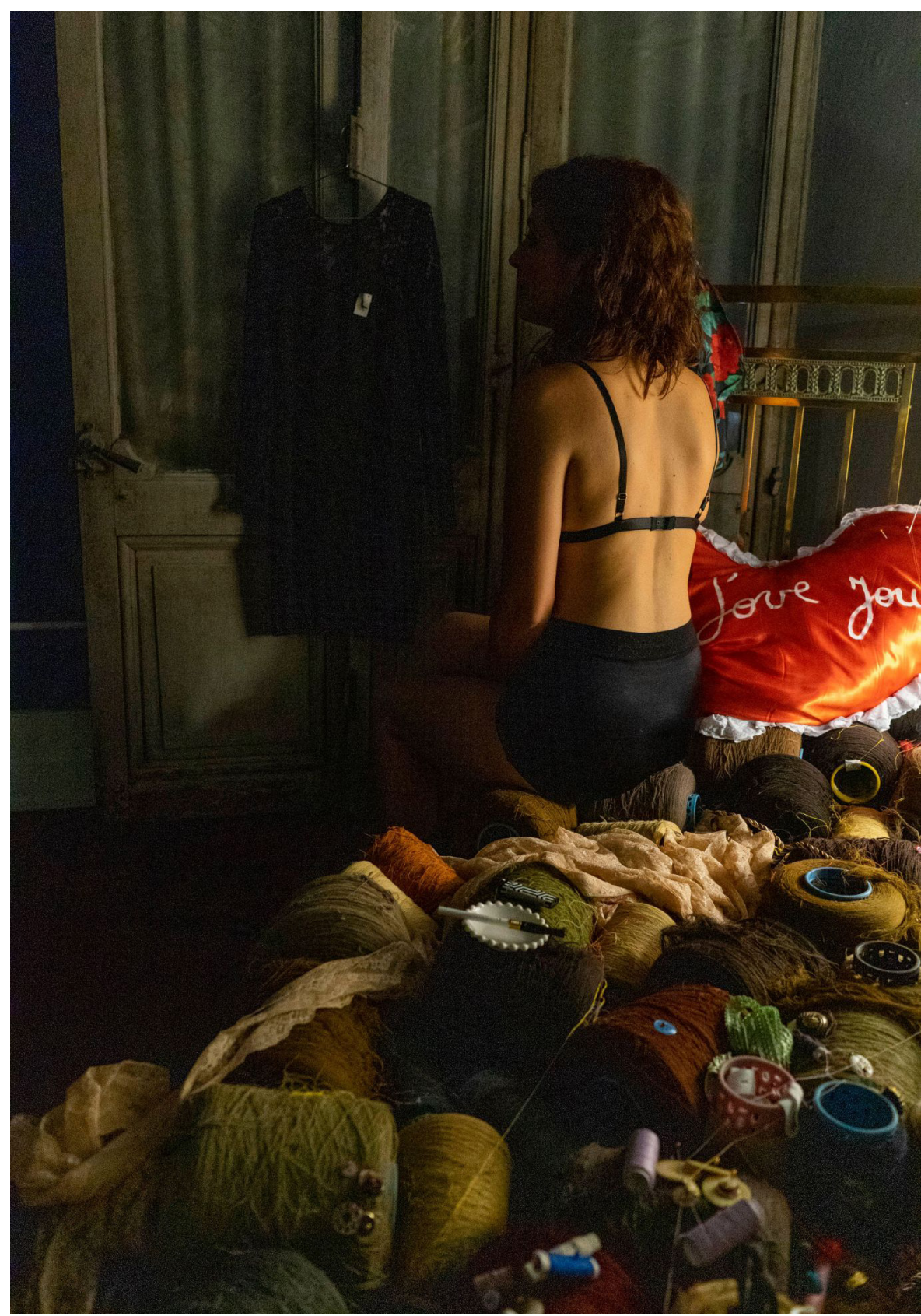


Ella está de espaldas, sentada en la cama, en ropa interior. Ver ese cuerpo casi desnudo en tanta proximidad nos interpela. El acercamiento es inminente. La cama está repleta de hilos y carretes, de agujas y tejidos. Sobre la cama hay un gran almohadón que dice "I love you", un aspecto cursi que luego se resignifica de un modo casi descarnado cuando se desarrolla la escena. Con voz en off y con escrituras en una pizarra que están mediadas por una técnica (Mavi Parada) que escribe in situ con una computadora textos elaborados por Paola, ella cuenta la historia de sus abuelas, fumando cigarrillos, metáfora del tiempo que se consume. La costura oficia de tejido textual pero el centro de las historia es la capacidad de la abuela Esther para escribir y cómo de algún modo ella escribía historias de otros. Esther se escribió y se contestó cartas de amor durante seis meses que fue el tiempo que duró el cortejo de Alberto y Chichí, dos amigos que lograron enamorarse y casarse a través de las palabras de Esther, porque ambos por separado le pedían que escribiera al otro. "Y no fue hasta después del casamiento que Esther les contara el asunto de las cartas. Se rieron de eso por años, pienso que aún se siguen riendo", dice la actriz. En su discurso, hay un detalle interesante que es la comparación casi constante con animales de los personajes de sus historias, como si cada uno tuviera algo de cría o de instinto para moverse de los lugares comunes. Un texto poético aparece en la pizarra y vuelan muchos pájaros sobre ese texto. El público es invitado a salir de la habitación.

\title{
d/g/h) Archipiélago de Asteria / Analía Valerio
}

\begin{abstract}
Dispersas por la casa y el tiempo, tres islas máquinas activan conexiones entre nosotras, las que estamos y las que venimos. Parecen compuestas de ofrendas, hilos yflores, pero son movimiento; trabajo y movimiento.
\end{abstract}

En un mueble, una actriz, (Analía Valerio) borda y borda. En su espalda está el logo de MQC. El otro grupo sale de la habitación. Ahora somos diez personas mirando bordar. El bordado como metáfora de años de silencio, de voces no escuchadas. Ese silencio domina la habitación que en realidad es un pasadizo exterior. Como si el bordado se colectivizara en la historia de mujeres, como si el bordado nos llevara por caminos similares, colectivos, intensos y conocidos. Hay elásticos. Ruedan en un entramado de muchos elásticos. Flexibilidades y tensiones que de algún modo recorren la vida de las mujeres en la historia. Y que continúa en otro momento en otro pasadizo

\section{Oblicua / Claudia Campos}

Oblicua es una ruina de lo aprendido ¿Quése cae? ¿Qué queda? Hay restos, brotes, trazos, viejos fantasmas...Oblicua está presente. Atravesada por un final y un principio, resiste.

Y se nos invita a pasar en dos frentes a un espacio abierto, en ruinas, habitado por Claudia Campos. El sonido es de una cajita musical. Hay ladridos de perros. Hay mucha oscuridad. Una linterna alumbra el espacio que recorre Claudia. Hay pizarrones escritos, plantas, maderas, mapas, dinteles, molduras arruinadas y en cada rincón algo nuevo para descubrir. Se escuchan corceles trotando, sonidos tétricos, casi prehistóricos y Claudia ilumina con su linterna cada rincón, cada intersticio y un bosque a escala. Agua que desdibuja el pizarrón. Sombras, pasos y una pintura que aparece iluminada. Los cuestionamientos que los espectadores pueden hacerse frente a estas circunstancias visuales y auditivas y ese cuerpo trasladándose entre las ruinas es una imagen de pérdida, desolación, escenarios errantes que dejan rastros en las almas. ¿Se trata de teatro o artes visuales? ¿A dónde emigró la palabra? 
Con estas preguntas se conduce al público al corredor a ver una mesa de libros, (parte del Archipiélago), muchos libros, para hojear, leer, disfrutar a modo de altar...Aquí está la palabra, aquí me encuentro con lo seguro, yo, público, veo y toco, percibo colores, flores, objetos sonoros y el silencio se impone. Alguna gente del público sólo mira de afuera, sin interactuar, otros buscamos, nos sumergimos, leemos. Un timbre suena y el público es invitado a entrar a otra habitación.

\section{f) Museo de Ramos Generales / Eliana Barrios}

Ubicado en una intersección temporal, este museo y almacén establece comunicación con lugares de una memoria a través de una colección de reliquias cotidianas que presentan lo que ha sido y lo que ahora no.

El público entra a un museo de objetos: secadores antiguos, carameleras, relojes, cajitas, instrumentos, lámparas, guantes, radios viejas. Una de las mujeres: Eliana Barrios, está frente a una computadora y luego va hacia un tablero de luces precario. En ese tablero pulsa interruptores y juega rítmicamente con ellos. Música primitiva, sonidos que se pulsan y que se coordinan con luces y sombras. En un rincón, un maniquí porta un antiguo abrigo. El juego de luces genera un ritmo interesante mientras la gente pasea por la instalación. Cada objeto tiene un letrero con la historia de ese objeto. De pronto, la mujer decide cambiar, va a un teléfono antiguo de pared y habla: "Tenemos una cajita con el número ocho y un vals de quinceañeras con el número siete. Pueden elegir, si quieren escuchar, tomando un número de la vitrina mayor, colocándolo en la barra" En esa interacción mediatizada con el público se trenzan las historias, como el pelo de la actriz que se trenza y se destrenza en un acto de intimidad reflexiva. Y así, vuelve a sacar sonidos, dándole la espalda al público, trenzándose la cabellera. En el ambiente suenan murmullos, voces, gritos intermitentes. La habitación pierde luz mientras avanzan los ruidos. Toma el teléfono- micrófono y le indica al público que se pueden mover y accionar sobre las luces del tablero mientras ella canta. Una canción de amor, de rupturas, de liberación. Un canto que suena, que se impregna en cada una de nuestras almas como aquel día en la peña, en el año 2018, sucedió con la directora de la obra. 


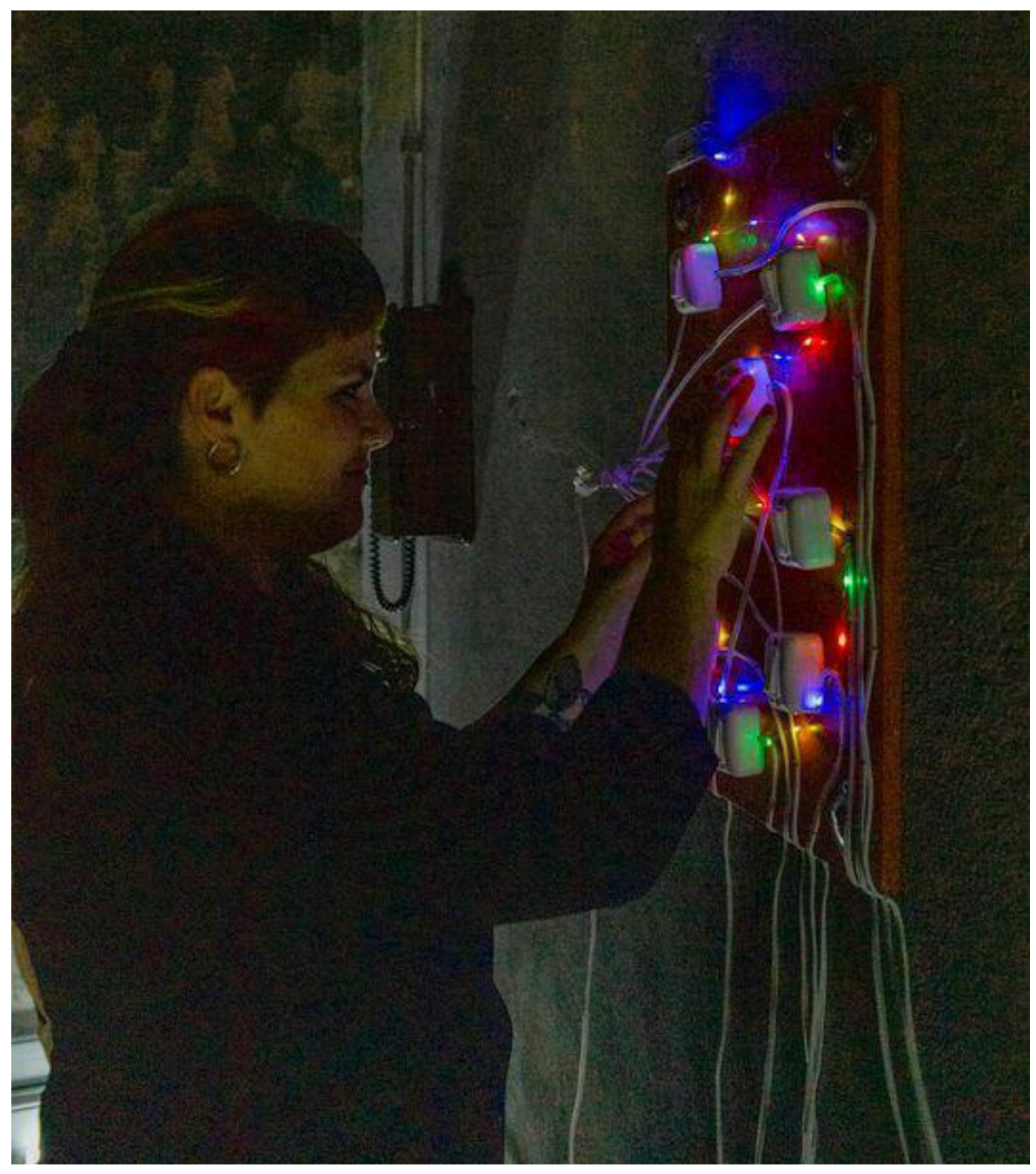

El público es invitado a salir de la habitación hacia una instalación de yuyos y plantas. Un cartel pende de un lado de la estantería: TU PROPIA FUERZA. La actriz (Analía Valerio) riega, manipula, acomoda, busca los distintos niveles de plantas y yuyos. Una metáfora de los rasgos inmanentes, de aquello que cuidamos, instalamos, de la vida que surge y se acomoda gracias a nuestras manos. Prende fuego a un palo con un olor muy muy intenso y nos invaden las sensaciones olfativas y táctiles. El agua que nos moja, que se desborda, que brota, la humedad de las plantas que nos introduce en el reino vegetal, en la vida transformada, en lo que es y depende de nuestros cuidados. El palo oloroso, cual antorcha, es entregado a nuestra guía que nos conduce por una escalera crujiente a un altillo.

\section{i) Nido caduco / María Inés Cabaleiro}

En esta oscuridad, los miedos se encienden vigilantes. Hay algo que se quiere interrumpir: ese sedimento confuso de sobras, de restos; esa basura acumulada de los días.

Una actriz: María Inés Cabaleiro, está en el altillo con una taza de té. Parece ciega. Se escuchan graznidos. Toma algunos pedazos de torta, se los lleva a la boca pero no los come. Suena un tango y muchas imágenes de ojos en movimiento, con miradas fijas, imprecisas, diversas, parecen bailar al ritmo de la música. Si la música se detiene, desaparecen las miradas proyectadas en la pared de ladrillos. Solamente se ilumina 
la cara de la actriz que está sentada detrás de muchas tazas y platos de té, teteras y comida. La actriz canta. Toma un avestruz de cartón de unos encajes que están debajo de la mesa. La actriz hace beber al ave inerte los contenidos de las tazas de té en un gesto inútil. Mientras suenan muchas voces. Y continúa cantando, parece estar vigilada y sentir esos ojos vigilantes. Su canto es como un grito íntimo, desgarrador.

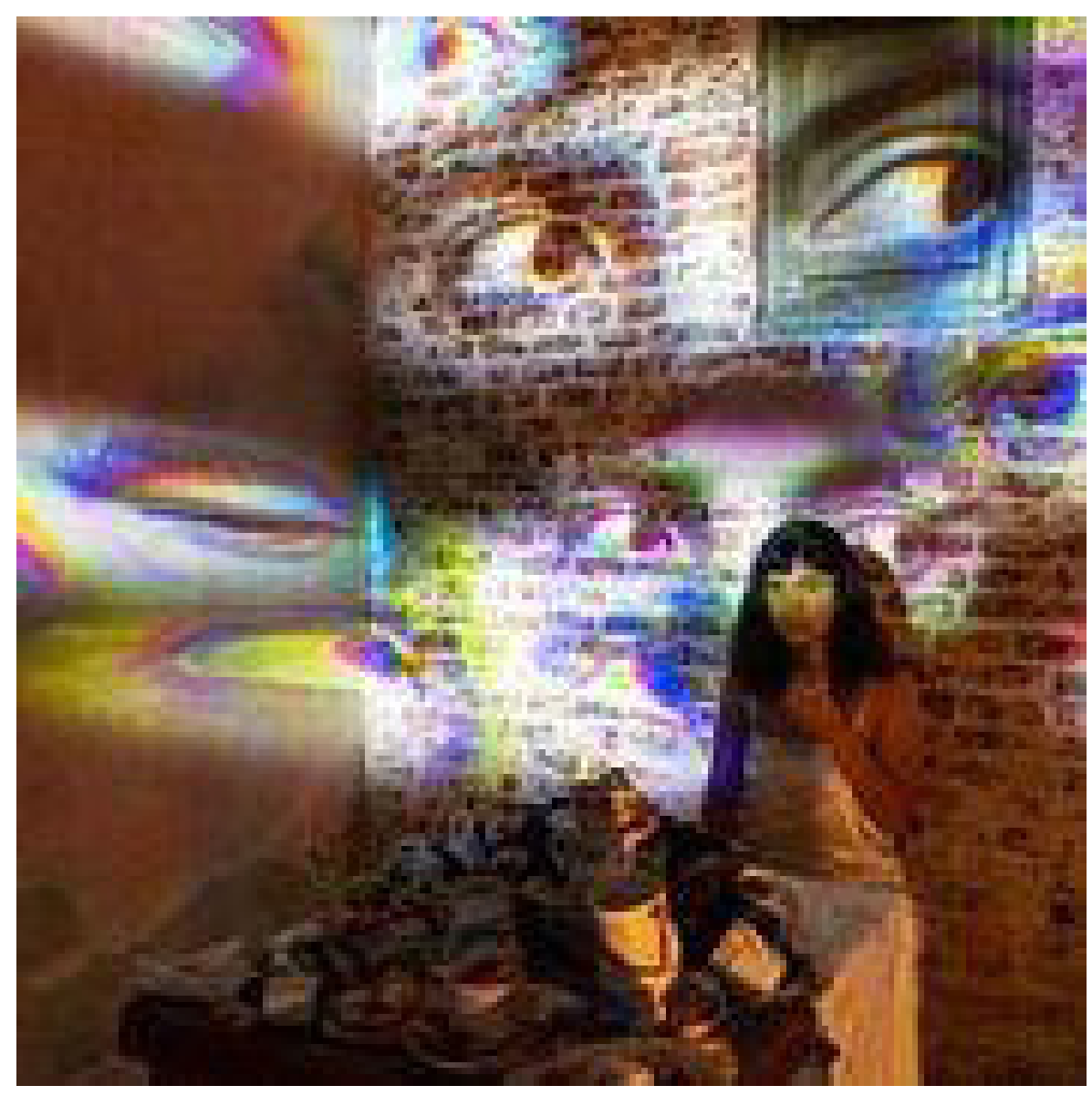

\section{j) La casa, el cielo / Natacha Chauderlot}

Esta es una plegaria visual para invocar a los pájaros. Un acto de reunión y contemplación para la conciencia. Entender es amar. Invoco la casa que enciende la casa, es el tiempo un bordado

Por último la gente es invitada a subir a la azotea. El público y las artistas. El paisaje celestial es hermoso. Se ven las cúpulas de otras casas, de la iglesia de la Plaza Matriz. En el piso hay una alfombra de pasto. Se invita al público a descalzarse. Natacha pone semillas en el pasto y todas las demás participantes caminan descalzas. Se prende fuego en una cazuela, Karen lleva su guitarra. Una taza de flores da vueltas sobre su eje

Invoco la casa que enciende,

la casa, en el humo, mi descanso.

Invoco la casa que enciende

la casa es el tiempo

bordado. 
Todas bajan de la alfombra e invitan al público a que recorra el camino consciente de tener los pies en la tierra. La gente se descalza y recorre el camino de pasto. La guitarra acompaña los pasos del público. La gente queda descalza y aplaude. Un ritual de despojos, un camino recorrido que nos lleva a lo más profundo de nuestra intimidad: los pies. Un camino invocado de una forma sutil, casi una caricia al alma. Y la cúpula de la Iglesia Matriz nos transporta al infinito celestial.

\section{Los registros oblicuos como parte y no parte de la representación}

Concluiremos este artículo haciendo eco de las palabras de la dramaturga - guía: "la obra es mucho más que las funciones, hace habitar el presente de un modo particular. Estar todo el tiempo." Se trata de un espectáculo cuestionador. Nos quedamos con la sensación de que las imágenes desbaratan los cierres interpretativos Nos quedamos con la idea de que enlazan lo visible y desvinculan sus significaciones, desvían sentidos. Porque las imágenes son mucho más que imágenes. Dice Alejandra Castillo: "La imagen es un estar afuera del tiempo que se expone, paradójicamente, en el tiempo" (2019: 328) Porque afecta, toca, para explicitar en esa descripción múltiples interpretaciones. Se altera el registro de lo visible y se altera el marco de lo recto, para volverse oblicuo. Y también los registros de la palabra, de la oralidad, mediatizados, pero también mudos Porque la escritura es el lugar de alteración y falla del dispositivo de la voz. Y las MQC han escrito y nos pusieron a escribir, las palabras se volvieron acciones, interlocuciones. La intangibilidad del tiempo estuvo presente y estas artistas, desde su casa, en tiempos de pandemia, crearon un espectáculo mínimo, íntimo, intenso, con ventanas y azoteas y también con aperturas y cierres. Nos llevaron de lo público a lo privado y volvieron a lo público con ese cierre celestial que mucho nos hace madurar la "imagen pensativa" de Rancière (2009) como registro oblicuo, parte y no parte del orden de la representación, dándonos mucho más de lo que la imagen deja ver. El combate, lo oblicuo, la elección propia, la vida afectiva y lo que la tradición de la cultura no puede soslayar es ese camino que conduce la femineidad desde lejos tejiendo los hilos de los relatos particulares que se encuentran en algún punto de las historias femeninas. La tensión entre el mundo íntimo y el universo celestial invoca la reflexión sensible, la necesidad de pensar y repensar la voz de las mujeres en la cultura. Las mujeres cantan y el espacio nos habita. Y en esos senderos recorridos queda mucho aún para escribir, narrar y cantar. 


\section{Q Bibliografía}

» Barthes, Roland (1980). La chambre claire: note sur la photographie. Paris:

" Gallimard.

" Bertherat, Thérèse: (1987). El cuerpo tiene sus razones. Buenos Aires: Paidós.

»Butler, Judith (2004). Lenguaje, poder, identidad. Madrid: Editorial Síntesis.

" Castillo, Alejandra (2019). "La imagen inclinada" en Democracias incompletas:

"debates críticos en el Cono Sur de Fernando A. Blanco y Cristián

"Opazo. Santiago: Editorial Cuarto Propio. 325-338.

»Rancière, Jacques (2009). El destino de las imágenes. Buenos Aires: Prometeo.

»Trastoy, Beatriz (2018). La escena posdramática. Ensayos sobre la

» autorreferencialidad. Buenos Aires: Libretto

»Otras fuentes:

»Entrevista por mail a Estibaliz Solís Carvajal realizada el 7 de diciembre de 2020

» Registro de la obra realizada por Ismael Krall

\section{Ficha técnica}

Obra: Mujeres que cantan

Colectivo La Tijera

Dirección y guía dramatúrgica: Estíbaliz Solís Carvajal

Elenco: Karen Halty, Paola Larrama, Analía Valerio, Claudia Campos, Eliana

Barrios, María Inés Cabaleiro, Natacha Chauderlot

Asistencia en Proyecciones: Mavi Parada

Fotografía: Bettina Rodríguez

Registro: Ismael Krall

Lugar: Proyecto Modo Casona (Emprendimiento de Carolina Ferreyra)

Ciudad Vieja de Montevideo

Estreno: 23 de noviembre de 2020 